\title{
ULTRAMAFIC LAMPROPHYRE DYKE SWARM, TORNGAT MOUNTAINS, QUEBEC AND LABRADOR: MINERALOGY AND GEOCHEMISTRY
}

\author{
Sebastian Tappe ${ }^{1}$, Stephen Foley ${ }^{1}$, George Jenner ${ }^{2}$, Bruce Ryan ${ }^{3}$, \\ Dean Besserer ${ }^{4}$ and Bruce Kjarsgaard ${ }^{5}$ \\ ${ }^{1}$ Greifswald University, Germany; ${ }^{2}$ Memorial University, Canada $;{ }^{3}$ Newfoundland Department of Mines and Energy, \\ Canada; ${ }^{4}$ Apex Geosciences Ltd., Canada $;{ }^{5}$ Geological Survey of Canada; Canada
}

\section{INTRODUCTION}

The borders of the Labrador Sea have been the site of widespread mafic-potassic to carbonatitic magmatism from the Proterozoic to the Mesozoic (Larsen and Rex, 1992). Most of the dyke and sheet intrusions were described as "kimberlitic". However, reclassification of some dyke occurrences (Mitchell et al., 1999) and new discoveries (Wardle et al., 1994, Digonnet et al., 2000) indicate that an appreciable amount of the alkaline magmatism is more akin to ultramafic lamprophyres (UML). The fact that these may also be diamondiferous even in off-craton settings like the Torngat orogen, demands a new petrogenetic model for their origin.

We have undertaken a detailed mineralogical and geochemical study of ultramafic lamprophyre samples from the Torngat Mountains (Fig.1). Their variability in modal abundances and mineralogical composition enables us to decipher their crystallisation history and to gain valuable information about the nature of primitive UML magma.
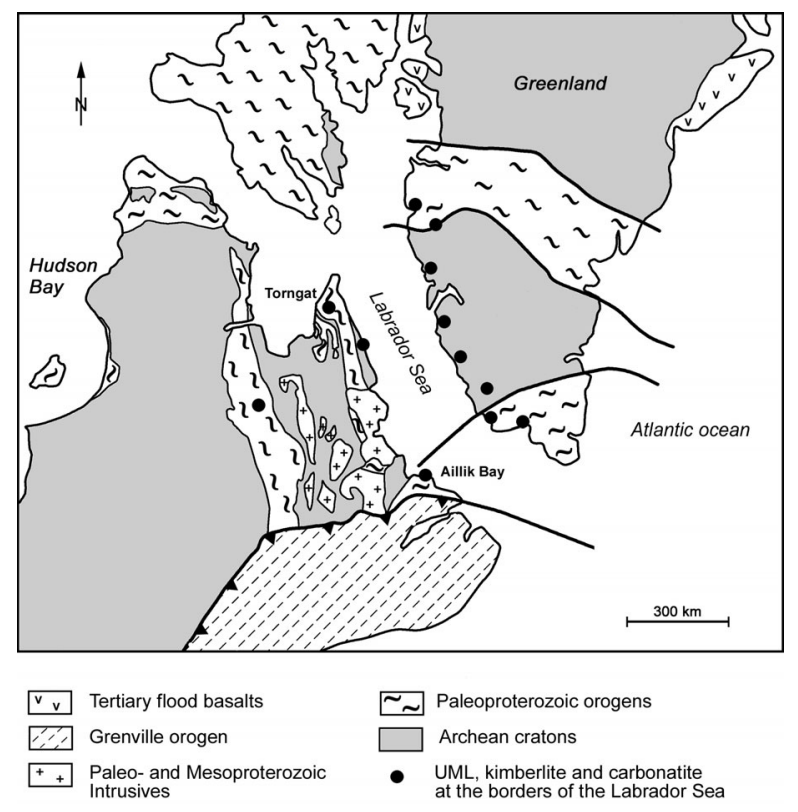

Fig.1: Geology of Labrador, New Quebec and Greenland

\section{PETROGRAPHY OF ROCK TYPES}

The Torngat dyke intrusions are best considered part of an ultramafic lamprophyre - carbonatite suite. Three major rock types have been recognized within the dyke swarm, listed in order of decreasing carbonate content: carbonatite, aillikite and melaaillikite. It should be emphasized that a complete modal and textural gradation exists between these rock varieties, representing a compositional continuum rather than discrete rock groups.

In aillikites and carbonatite a macrocrystal to porphyritic texture results from abundant anhedral to subhedral olivine crystals several $\mathrm{mm}$ in diameter, and widespread, zoned phlogopite crystals, which are sometimes flow-oriented. A second generation of olivine and phlogopite is set in a groundmass composed of carbonate, phlogopite and minor serpentine. Abundant euhedral opaque oxides and rounded perovskite or rutile grains are scattered throughout the matrix in which apatite and sporadically clinopyroxene form slender elongate prisms. Carbonates may form a mosaic of calcite crystals exceeding 10 vol \% of the mineral mode and fine dispersed carbonate occurs as schlieren. In the carbonatite, the groundmass is comprised of a medium-grained mosaic of ferrodolomite and subordinate breunnerite crystals (51 vol \% carbonate).

The melaaillikites show an intergranular texture which is only subordinately porphyritic. Olivine dominates the less abundant macro- and phenocryst assemblage as in the aillikites. Phlogopite is ubiquitous and forms up to 5 $\mathrm{mm}$ large poikilitic plates. Clinopyroxene, olivine, apatite, opaques and carbonate are set between the dominant mica laths and plates. The modal proportions of clinopyroxene are significantly higher than in the aillikites reaching up to $20 \mathrm{vol} \%$. Some melaaillikites contain a pale brown richteritic amphibole, which may approach the same high modal abundances as the coexisting clinopyroxene. Carbonate occurs only in interstices and ocelli-like segregations, typically not exceeding $10 \mathrm{vol} \%$. This gives rise to apply the prefix "mela" in distinction to most aillikites, which are 
modally poorer in mafic silicate minerals and richer in carbonate (Rock, 1986). Furthermore, the amount of opaque oxides is only half as much as in the aillikites. Perovskite or rutile are scattered throughout the intergranular matrix with perovskite reaching up to 11 vol $\%$. Titanite is restricted to the melaaillikites and was often found to replace rutile grains.

Igneous Ti-andradite and kimzeyite as well as xenocrystic $\mathrm{Cr}$-pyrope and almandine pyrope occur in all rock types. The latter garnets classify as G9 and G5 and are probably derived from mantle lherzolites and lower crustal rocks, respectively.

\section{MINERAL CHEMISTRY}

The mineralogical composition of the Torngat ultramafic dykes is clearly of lamprophyric affinity exhibiting significant differences to that observed in archetypal kimberlite.

Only a few samples contain unaltered macrocrystal and phenocrystal olivine. The core compositions are between 81-93 Fo (rarely as low as 76) displaying a much wider range than known from archetypal kimberlites $(>84)$. The rim compositions converge upon Fo 82-88 regardless of whether zoning is normal or reversed. A second olivine generation has the same composition as the overgrowth mantling on the macrocrysts and phenocrysts.

Micas from all three rock types represent solid solutions between the phlogopite, tetraferriphlogopite, annite and eastonite end-members. The aillikite phlogopites are characterized by lower $\mathrm{Ti}$ content than their melaaillikitic analogues with a somewhat arbitrary boundary at about $4 \mathrm{wt} \% \mathrm{TiO}_{2}$. Melaallikite micas contain up to $8 \mathrm{wt} \% \mathrm{TiO}_{2}$. Two contrasting core-rim evolutionary trends have been observed in the weakly zoned aillikite and melaaillikite micas. Those in the aillikites show a trend toward tetraferriphlogopite with increasing $\mathrm{Fe}$ and strongly decreasing $\mathrm{Al}$ at constant Mg. Nearly Al-free discrete tetraferriphlogopite rims are restricted to the aillikites. The melaaillikite micas show a trend toward biotite, with increasing $\mathrm{Fe}$ and decreasing Mg but nearly constant Al. Discrete darkbrown biotite rims were only found in the melaaillikites, sometimes altered to Fe-Mg chlorite. The microphenocrystal flakes and plates are characterized by homogeneously low $\mathrm{Ba}$ and $\mathrm{F}$ contents (below 1.0 and $1.5 \mathrm{wt} \%$, respectively), clearly distinct from kimberlitic groundmass micas of the phlogopitekinoshitalite series.

The rare clinopyroxene from the aillikites is nearly pure diopside, whereas the abundant melaaillikitic diopsides show highly variable $\mathrm{Mg} / \mathrm{Fe}^{2+}$ ratios approaching salitic compositions. Additionally, these latter crystals are characterized by a high proportion of the $\mathrm{Ca}-\mathrm{Ti}$ Tschermaks molecule (up to 5 wt $\% \mathrm{Al}_{2} \mathrm{O}_{3}$ and $7 \mathrm{wt} \%$ $\mathrm{TiO}_{2}$, Fig.2). Clinopyroxenes are extensively zoned displaying normal rimward trends of $\mathrm{Na}$ and $\mathrm{Fe}$ enrichment but $\mathrm{Mg}$ depletion (up to $19 \mathrm{~mol} \%$ aegirine). This sector variation is coupled with increasing $\mathrm{Al}$ and Ti content.

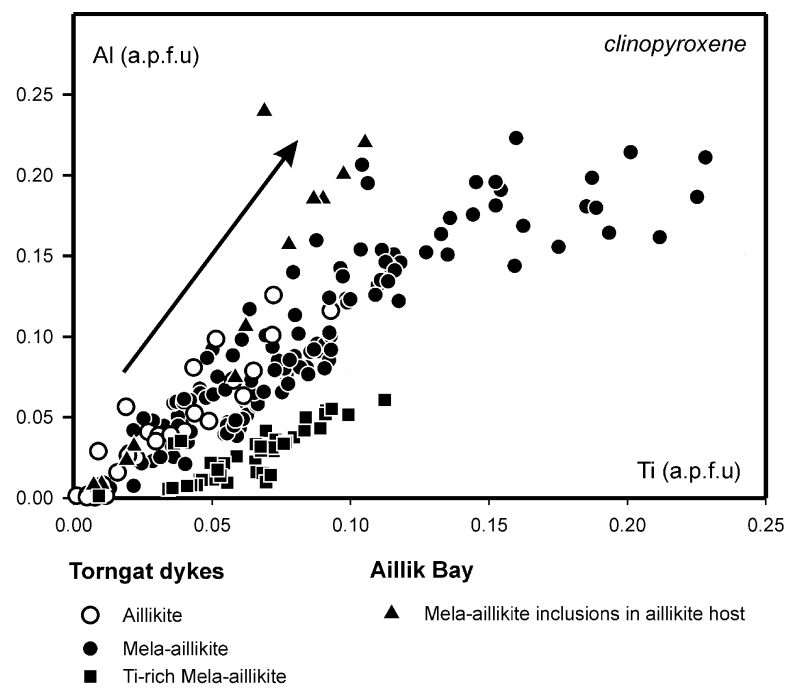

Fig.2: Compositional variation of clinopyroxenes in Torngat dykes. Note the coincidence of trends from Torngat melaaillikites and Aillik Bay inclusions.

Amphibole compositions are intermediate between the end-members magnesiokatophorite and richterite, but in contrast to typical lamproitic and orangeitic richterites $\mathrm{Na}$ dominates over $\mathrm{K}(\mathrm{K} / \mathrm{Na}<0.3)$. The Ti content in amphiboles of all these potassic rock types is comparably high (up to $5.5 \mathrm{wt} \% \mathrm{TiO}_{2}$ ) and the $\mathrm{F}$ content amounts to less than $0.8 \mathrm{wt} \%$. Compositional zoning trends show an increase in $\mathrm{Al}$, $\mathrm{Ti}$ and $\mathrm{Fe}$ but decreasing $\mathrm{Mg}$ content from core to rim.

The spinel group minerals occur as composite crystals rather than single-phase grains representing three broad compositions listed in order of increasing abundance: (1) xenocrystic spinel - chromite solid solutions, (2) titanian magnesiochromite - chromite solid solutions with typically less than $5 \mathrm{wt} \% \mathrm{Al}_{2} \mathrm{O}_{3}$ and (3) ulvöspinel - magnesian ulvöspinel - magnetite solid solutions with commonly less than 2 wt $\% \mathrm{Al}_{2} \mathrm{O}_{3}$. The $\mathrm{Fe} / \mathrm{Mg}$ ratio in the Ti-magnetites exhibit slight differences between aillikites and melaaillikites: slightly lower in the aillikites following a kimberlitic trend (trend 2) and probably reflecting a higher oxygen fugacity. Ilmenite represents a solid solution series between $\mathrm{FeTiO}_{3}$ and $\mathrm{MgTiO}_{3}$ (up to $10 \mathrm{wt} \% \mathrm{MgO}$ ) with some solid solution toward hematite. The Mn content is variable $(0.3-11 \mathrm{wt}$ 
$\%)$ and is intermediate between Mn-depleted ilmenites from kimberlite and carbonatitic high-Mn ilmenites. Most importantly, these ilmenites are distinct from their kimberlitic counterparts in being Cr-poor (below $0.2 \mathrm{wt}$ $\% \mathrm{Cr}_{2} \mathrm{O}_{3}$ ), a feature more akin to ilmenites from carbonatites.

Perovskite and rutile do not coexist in the UML dykes, indicating a reaction relation in a $\mathrm{CO}_{2}$-rich environment. This is consistent with the observation that rutile grains occur in samples with the highest modal carbonate abundances. Chemically, the rutiles are rather homogeneous and approach ideal composition. The highest observed $\mathrm{Nb}_{2} \mathrm{O}_{5}$ content is $1.44 \mathrm{wt} \%$, much lower than in many kimberlites.

Most of the perovskites are close to the ideal $\mathrm{CaTiO}_{3}$ composition containing less than $10 \mathrm{~mol} \%$ other endmembers. A strong negative correlation between atomic $\mathrm{Ca}$ and atomic $\mathrm{Na}$ plus REE favours a main solid solution series between perovskite and loparite $\left(\mathrm{Na}_{0.5} \mathrm{Ce}_{0.5} \mathrm{TiO}_{3}\right)$. Perovskites in the carbonate-rich aillikites contain less $\mathrm{SrO}$ (below 0.38 wt \%) and $\mathrm{Nb}_{2} \mathrm{O}_{5}$ (below $0.58 \mathrm{wt} \%$ ) than in the carbonate-poorer melaaillikites.

Titanite is restricted to the interstices of some melaaillikites and is relatively Fe-rich (5.4 wt \% $\mathrm{Fe}_{2} \mathrm{O}_{3}$ ). Relict rutile grains overgrown by titanite indicate a replacement reaction in the sample with the highest $\mathrm{SiO}_{2}$ content.

Contemporaneous carbonate and apatite crystallization is indicated by calcite inclusions in apatite. The F content is rather high and there is a tendency for the melaaillikitic apatites to be F-richer (up to $3 \mathrm{wt} \%$ ) than their aillikitic counterparts which rarely exceed 2 wt \% F. Furthermore, a significant amount of Si (up to $2.7 \mathrm{wt}$ $\% \mathrm{SiO}_{2}$ ) substitutes for $\mathrm{P}$ in the apatites from aillikites probably coupled with a higher REE content than in melaaillikitic apatites. The latter contain appreciable amounts of S reaching up to $1 \mathrm{wt} \%$. The Sr content can be regarded as rather low (below $1 \mathrm{wt} \%$ ) in comparison to apatites from orangeites.

A diagnostic accessory for UML is titanian andradite, which may occur in both aillikites and melaaillikites. Schorlomitic compositions with $\mathrm{Ti}$ greater than 0.5 atoms per formula unit dominate but pure andradite was also found in contact with the schorlomite. A primary igneous nature is indicated by its poikilitic habit and the replacement of groundmass clinopyroxene.

Zirconian schorlomite and kimzeyite with up to $18 \mathrm{wt}$ $\% \mathrm{ZrO}_{2}$ are the most exotic compositions; so far these minerals have been reported from carbonatites, UML, shoshonites and kamafugitic ejecta (e.g. Schingaro et al., 2001).

\section{GEOCHEMISTRY}

The ultramafic Torngat dykes are characterized by high $\mathrm{MgO}\left(10-25\right.$ wt \%), $\mathrm{CaO}(5-20), \mathrm{TiO}_{2}(3-10)$ and $\mathrm{K}_{2} \mathrm{O}$ (1-4) but low $\mathrm{SiO}_{2}(22-35)$ and $\mathrm{Al}_{2} \mathrm{O}_{3}$ (2-6) contents and represent primitive potassic melts undersaturated with respect to silica.

The melaaillikites are distinguished from the aillikites by higher $\mathrm{Si}, \mathrm{Al}, \mathrm{Na}$ and lower $\mathrm{CO}_{2}$ content reflecting their higher modal clinopyroxene and amphibole but lower carbonate abundances.

Trace element concentrations of all samples are extremely high and there are only subtle differences in incompatible elements between carbonatite/aillikite and melaaillikite. The rare-earth elements show a wide range of fractionation $\left(\mathrm{La}_{\mathrm{N}} / \mathrm{Yb}_{\mathrm{N}}\right.$ 58-204) probably as a consequence of fluctuating modal abundances of the numerous REE-bearing phases.

Both aillikite/carbonatite and melaaillikite have a common, less fractionated primitive mantle-normalized incompatible element pattern. The only troughs occur at $\mathrm{K}$, Sr-P and Zr-Hf. The Zr-Hf trough, decoupled from $\mathrm{Ti}$, is deepest for the carbonatites/aillikites and is not present in some melaaillikites. These relative depletions may indicate a major role for residual phlogopite, carbonate, apatite and clinopyroxene in the mantle source.

\section{DISCUSSION}

Prerequisite to an understanding of the petrogenesis of ultramafic lamprophyres is an evaluation of the relations between the different UML types and allied rock groups such as kimberlite and kamafugite. The following should only serve to illuminate the potential relations between the members of the Torngat dyke swarm, before we start to put constrains on mantle processes, which is a future goal of this project.

\section{DIFFERENTIATION}

The mineralogically distinct members of the Torngat dyke swarm represent a compositional continuum with overlapping bulk major element concentrations, similar REE distribution and comparably high incompatible element abundances. This implies related parental magmas, but the range in composition cannot be explained in terms of fractional crystallization. Olivine and Cr-spinel fractionation only accounts for the intragroup variation of aillikites and melaaillikites.

Variations in mineralogical modes and trends between the members of the dyke swarm are recognized. 
Furthermore, amongst the vast number of constituent minerals, many incomplete reaction relations have been observed: e.g. phlogopite-olivine, amphibole-cpx, carbonate-cpx, schorlomite-cpx, titanite-rutile and rutile-perovskite. This leads us to suggest that carbonatite, aillikite and melaaillikite crystallized from a common magma type but under different $\mathrm{P}, \mathrm{T}$, volatile conditions with the failure of reactions to proceed to completion as the magma moved toward the surface.

Melaaillikites seem to have crystallized over a greater temperature range than the aillikites and under lower $\mathrm{CO}_{2} / \mathrm{H}_{2} \mathrm{O}$ ratios. This is indicated by their coarser intergranular texture and by their distinct modal phlogopite, amphibole and carbonate content. A higher crystallization temperature for melaaillikites can be deduced from higher $\mathrm{Ti}$ concentrations in phlogopite (Guo and Green, 1990) at comparably high bulk-rock $\mathrm{Ti}$ concentrations for all rock types. More reduced conditions during late crystallization stages are reflected by a biotite trend rather than a tetraferriphlogopite trend as observed in aillikites.

The aillikites crystallized under $\mathrm{CO}_{2}$-rich conditions which suppressed the precipitation of clinopyroxene.

A lower relative HF-fugacity for aillikites than for melaaillikites was calculated from the $\mathrm{F}-\mathrm{OH}$ distribution between coexisting apatite and phlogopite (Zhu and Sverjensky, 1992). The higher HF-fugacity in melaaillikites is accompanied by a high $\mathrm{H}_{2} \mathrm{~S}$-fugacity as is indicated by higher sulphur content in late apatites and abundant modal sulphides.

All these points indicate a higher crystallization depth for the melaaillikites in a less open system than is to be expected for the carbonatites and aillikites.

\section{COMPARISON WITH TYPE AILLIKITES, LABRADOR}

Samples from Aillik Bay, the type locality of carbonate-rich ultramafic lamprophyres, provide evidence for the heteromorphic relation between Torngat aillikites and melaaillikites. The type aillikite contains several types of undeformed mica-rich inclusions, in which glimmerite nodules predominate. Olivine-phlogopite-clinopyroxene-spinel rocks with an igneous texture occur as cm-sized inclusions showing no signs of chemical reaction with the host aillikite other than some carbonate infiltration. Texturally and mineralogically they resemble the Torngat melaaillikites (Fig.2, Fig.3).

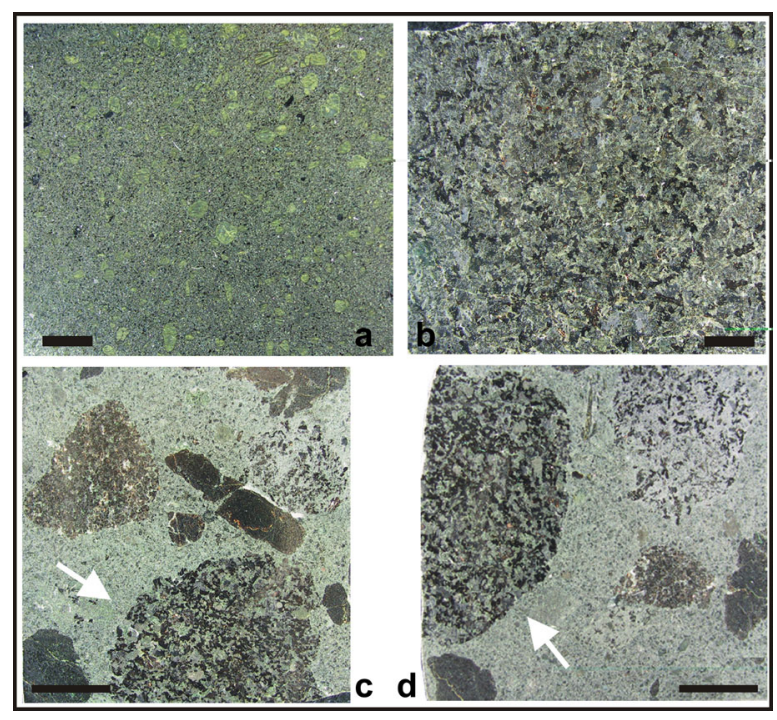

Fig. 3: Polished section blocks of UML from the Torngats (ab) and Aillik Bay (c-d). (a) macrocrystal aillikite with several mm large olivines. (b) intergranular melaaillikite dominated by mica, olivine and acicular cpx. (c-d) cognate inclusions embedded in aillikite.

Arrows in $\mathrm{c}$ and $\mathrm{d}$ point to igneous-textured olivine-micapyroxene-spinel autoliths resembling the melaaillikite from the Torngats in $\mathrm{b}$. Scale bars are $1 \mathrm{~cm}$.

At Aillik Bay these "melaaillikite" inclusions may result from an ultramafic lamprophyre magma that was identical but less $\mathrm{CO}_{2}$-laden than the subsequent aillikitic magma batch that incorporated autolithic fragments and explosively intruded higher levels.

The classic igneous-textured inclusions in African type kamafugites [O.B.P. suite of Holmes (1950)] also resemble the melaaillikites and a petrogenetic relation between UML, kamafugites and melilitites has to be investigated in the future.

\section{REFERENCES}

Digonnet, S., Goulet, N., Bourne, J., Stevenson, R., and Archibald, D., 2000, Petrology of the Abloviak Aillikite dykes, New Québec: evidence for a Cambrian diamondiferous alkaline province in northeastern North America: Can. J. Earth Sci., v. 37, p. 517-533.

Guo, J., and Green, T.H., 1990, Experimental study of barium partitioning between phlogopite and silicate liquid at upper-mantle pressure and temperature: Lithos, v. 24, p. 83-95.

Holmes, A., 1950, Petrogenesis of katungite and its associates: American Mineralogist, v. 35, p. 772-792. 
Larsen, L.M., and Rex, D.C., 1992, A review of the $2500 \mathrm{Ma}$ span of alkaline-ultramafic, potassic and carbonatitic magmatism in West Greenland: Lithos, v. 28, p. 367402.

Mitchell, R.H., Scott-Smith, B.H., and Larsen, L.M., 1999, Mineralogy of ultramafic dikes from the Sarfartoq, Sisimiut and Maniitsoq areas, West Greenland, in Gurney, J.J., Gurney, J.L., Pascoe, M.D., and Richardson, S.H., eds., Proceedings of the VIIth international kimberlite conference, Volume 2: Cape Town, Red Roof Design, p. 574-583.

Rock, N.M.S., 1986, The Nature and Origin of Ultramafic Lamprophyres: Alnöites and Allied Rocks: Journal of Petrology, v. 27, p. 155-196.

Schingaro, E., Scordari, F., Capitanio, F., Parodi, G., Smith, D.C., and Mottana, A., 2001, Crystal chemistry of kimzeyite from Anguillara, Mts. Sabatini, Italy: European Journal of Mineralogy, v. 13, p. 749-759.

Wardle, R.J., Bridgewater, D., Mengel, F., Campbell, L., Van Kranendonk, M.J., Hauman, A., Churchill, R., and Reid, L., 1994, Mapping in the Torngat Orogen, northernmost Labrador: Report 3, the Nain Craton (including a note on ultramafic dyke occurrences in northernmost Labrador): Current Research, Newfoundland Department of Mines and Energy, v. 941, p. 399-407.

Zhu, C., and Sverjensky, D.A., 1992, F-Cl-OH partitioning between biotite and apatite: Geochimica et Cosmochimica Acta, v. 56, p. 3435-3467.

Contact: S Tappe, Jahnstrasse 17a, 17491 Greifswald,

Germany, tappe@uni-greifswald.de

Note: we acknowledge the generous contribution of samples for our study by Marum Resources Inc., Dumont Nickel Inc. and International Tower Hill Mines Ltd. 